\title{
PENGARUH SUBTITUSI TEPUNG IKAN DENGAN TEPUNG BERNACLE TERHADAP BERAT ORGAN PENCERNAAN DAN LEMAK ABDOMINAL KELINCI PEDAGING JANTAN (Orytolagus cuniculus)
}

\author{
Bodhi Agustono*1), Maya Nurwartanti Yunita ${ }^{2)}$, Sunaryo Hadi Warsito ${ }^{1)}$, Widya Paramita Lokapirnasari ${ }^{1)}$, \\ Mohammad Anam Al Arif ${ }^{1)}$, Ragil Angga Prastiya ${ }^{3)}$, Amung Logam Saputro ${ }^{4)}$. \\ 1) Departemen Peternakan, Fakultas Kedokteran Hewan Universitas Airlangga Kampus C UNAIR Mulyorejo, \\ Surabaya, Jawa Timur, Indonesia 60115 \\ ${ }^{2)}$ Departemen Patologi Veteriner, Fakultas Kedokteran Hewan Universitas Airlangga Kampus C UNAIR \\ Mulyorejo, Surabaya, Jawa Timur, Indonesia 60115 \\ ${ }^{3)}$ Departemen Reproduksi Veteriner, Fakultas Kedokteran Hewan Universitas Airlangga Kampus C UNAIR \\ Mulyorejo, Surabaya, Jawa Timur, Indonesia 60115 \\ ${ }^{4)}$ Departemen Klinik Veteriner, Fakultas Kedokteran Hewan Universitas Airlangga Kampus C UNAIR \\ Mulyorejo, Surabaya, Jawa Timur, Indonesia 60115 \\ E-mail: bodhiagustono@fkh.unair.ac.id \\ Diterima Pasca Revisi: 26 Februari 2020 \\ Layak Diterbitkan: 1 Maret 2020
}

\begin{abstract}
ABSTRAK
Tujuan dari penelitian ini adalah untuk mengetahui pengaruh tepung teritip (Cirripedia sp.) Sebagai pengganti pakan dari tepung ikan pada pakan kelinci, seperti yang diamati dari lemak abdominal dan berat organ pencernaan kelinci jantan rex. Kelinci sebanyak 100 ekor ditempatkan pada kandang individu dengan pakan standart yang sesuai kebutuhan mereka secara ad libitum. Persentase feed substitusi dengan tepung teritip dengan empat perlakuan dan lima replikasi dalam pakan P0 (TI 15\% dan TT 0\%), P1 (TI 12,5\% dan TT 2,5\%), P2 (TI 10\% dan TT 5\%), P3 (TI 7,5\% dan TT 7,5\%). Perlakuan dilakukan selama 4 minggu, data dikumpulkan setelah pengorbanan akhir perlakuan. Usus kecil kelinci dikumpulkan dan menimbang organ pencernaan termasuk lambung, usus kecil dan usus besar. Hasil penelitian dianalisis menggunakan analisis varians dengan tingkat signifikansi 0,05. Berdasarkan hasil analisis menunjukkan bahwa tidak ada perbedaan yang signifikan $(p>0,05)$ pada lemak perut. Hasil penelitian menunjukkan tidak ada perbedaan yang signifikan $(p>0,05)$ dalam berat organ pencernaan (lambung, usus kecil, dan usus besar). Tepung teritip dapat digunakan sebagai pakan pengganti tepung ikan dalam pakan lengkap untuk kelinci jenis rex hingga $7,5 \%$.
\end{abstract}

Kata kunci: Bernacle, pakan pengganti, organ pencernaan.

How to Cite:

Agustono, B., Yunita, M.N., Warsito, S.H., Lokapirnasari, W.P., Al Arif, M.A., Prastiya, R. A., \& Saputro, A. L. (2020). Pengaruh Subtitusi Tepung Ikan Dengan Tepung Bernacle Terhadap Berat Organ Pencernaan dan Lemak Abdominal Kelinci Pedaging Jantan (Orytolagus cuniculus). Jurnal Nutrisi Ternak Tropis 3 (1) 41-47
*Corresponding author:

Bodhi Agustono

Email: bodhiagustono@fkh.unair.ac.id

Departemen Peternakan, Fakultas Kedokteran Hewan Universitas Airlangga Kampus C UNAIR Mulyorejo, Surabaya, Jawa Timur, Indonesia 60115 


\section{ABSTRACT}

The study aimed was to determine the effect of barnacle flour (Cirripedia sp.) as a substitution feed from the fish meal on rabbit feed, as observed from the abdominal fat and the internal organ of male rabbit. 100 rabbits are placed in individual cages with standard feed according to their needs ad libitum. Percentage feed substitution with barnacle flour with four treatments and five replications in feed PO (TI 15\% and TT 0\%), P1 (TI 12.5\% and TT 2.5\%), P2 (TI 10\% and TT 5\%), P3 (TI 7.5\% and TT 7.5\%). The treatment was carried out for 4 weeks, data were collected after the final sacrifice of the treatment. Small intestine of rabbits were collected and weighing the digestive organs including the stomach, small intestine and large intestine. The results of the research were analyzed using analysis of variance with a significance level of 0.05. Based on the results of the analysis showed that there were no significant differences ( $p>0.05$ ) on abdominal fat. The results showed no significant difference $(p>0,05)$ in weight of digestive organ (stomach, small intestine, and large intestine). Barnacle flour can be used as a feed for fish meal substitution in complete feed for rex type rabbit up to $7.5 \%$.

Keywords: Bernacle, substitution feed, digestive organ

\section{PENDAHULUAN}

Kelinci memiliki tingkat pertumbuhan dan reproduksi yang tinggi sehingga dapat digunakan sebagi alternatif untuk memenuhi kebutuhan daging nasional. Kelinci dapat melahirkan anak sebanyak 1-8 anak dalam sekali siklus kelahiran, dalam satu tahun kelinci dapat melahirkan hingga 8 kali (Raharjo dan Brahmantiyo, 2014). Pertumbuhan dan reproduksi kelinci dipengaruhi oleh manajemen pemeliharaan, menejemen pemeliharaan meliputi pakan, kandang,dan pemeliharaan (Usman dan Tiro, 2015; Giritya 2013). Beberapa kendala dalam usaha peternakan antara lain tingginya biaya pakan, tingginya biaya pakan dipengaruhi oleh mahalnya bahan baku pakan tersebut khususnya bahan pakan sumber protein, maka diperlukan bakan pakan alternatif untuk menurunkan biaya pakan tersebut, salah satu alternatif bakan pakan sumber protein yaitu teritip (Siregar, 2003).

Teritip merupakan hewan crustacea yang hidup di sepanjang pesisir pantai dan banyak dijumpai menempel pada substarat seperti dermaga, bawah kapal, batu, dan mabkhluk hidup seperti penyu, paus, dan lainnya (Ermaitis, 1984). Teritip belum banyak dimanfaatkan dan cenderung bersifat sebagai hama merugikan bagi substrat yang ditempelinya (Mirza,dkk,. 2017). Efisiensi dalam pakan tidak lepas hubungannya dengan fisiologi sistem pencernaan. Pakan yang mengandung protein yang baik dapat diserap tubuh lebih baik dibanding dengan bahan pakan dengan kadar protein yang lebih sedikit dan akan digunakan untuk pertumbuhan jaringan tubuh sehingga dapat berpengaruh untuk peningkatan bobot badan yang baik serta diikuti dengan penigkatan produksi karkas serta adanya lemak dalam tubuh ternak (Lebas dkk., 1986). Fisiologi sistem pencernaan memiliki peran penting dalam proses penyerapan nutrisi untuk kelangsungan kehidupan tubuh dan pertumbuhan bobot badan (Wresdiyati, dkk., 2015).

\section{MATERI DAN METODE}

Penelitian ini bersifat eksperimental yaitu bertujuan untuk mengetahui pengaruh pemberian tepung teritip sebagai feed substitusi tepung ikan dalam pakan kelinci dilihat dari berat organ pencernaan bagian lambung, usus halus, usus besar dan lemak abdominal. Kelinci ditempatkan pada kandang individu dengan pakan standart yang sesuai kebutuhan mereka secara ad 
libitum. Penelitian ini menggunakan rancangan acak lengkap (RAL) dengan 4 perlakuan dan 5 ulangan. Kelinci yang digunakan dalam penelitian sebanyak 100 ekor yang terbagi menjadi 4 perlakuan dengan 25 ekor pada masing-masing perlakuan. Dari masing perlakuan terbagi menjadi 5 ulangan dengan 5 ekor pada masin-masing ulangan. Pakan yang digunakan adalah sebagai berikut:

P0 = (tepung teritip 0\% dan tepung ikan $15 \%)$

$\mathrm{P} 1=$ (tepung teritip $2,5 \%$ dan tepung ikan $12,5 \%)$,

$\mathrm{P} 2=$ (tepung teritip 5\% dan tepung ikan $10 \%)$

P3 = (tepung teritip 7,5\% dan tepung ikan $7,5 \%)$.

Pengumpulan data di peroleh dari penimbangan organ pencernaan bagian lambung, usus halus, usus besar, dan lemak abdominal. Data yang diperoleh lalu diolah menggunakan uji analisis of varians (ANOVA).

\section{HASIL DAN PEMBAHASAN}

1. Berat organ lambung

Hasil berat organ pencernaan bagaian lambung adalah sebagai berikut:

Berdasarkan hasil analisis uji ANOVA tidak terdapat perbedaan yang nyataantara kelompok perlakuan dan kontrol $(\mathrm{P}>0.05)$. hal ini dapat disebabkan karena kandungan nutrisi dalam pakan yang digunakan antara kelompok perlakuan dan kontrol tidak terdapat perbedaan yang signifikan. Pertambahan berat organ pada kelinci dipengaruhi oleh jumlah pakan yang dikonsumsi, kandungan pakan, usia, dan bentuk pakan.(Tambunan, 2015). Semakin banyak pakan yang dikonsumsi oleh kelinci maka akan menyebabkan semakin berat kerja dari lambung tersebut, sehingga menyebabkan lambung mengalami adaptasi baik secara hipertofi maupun hiperplasia untuk meningkatkan kebutuhan fungsional, sehingga otot lambung menjadi menebal untuk menjaga fungsi lambung (Arimbi dkk.,2015).

Tabel 1. Berat lambung rata-rata setiap kelompok perlakuan

\begin{tabular}{cc}
\hline Perlakuan & Rata-rata $(\mathrm{g}) \pm \mathrm{SD}$ \\
\hline P0 & $45,40 \pm 4,45$ \\
P1 & $54,60 \pm 7,43$ \\
P2 & $49,80 \pm 9,57$ \\
P3 & $49,00 \pm 6,20$ \\
\hline
\end{tabular}

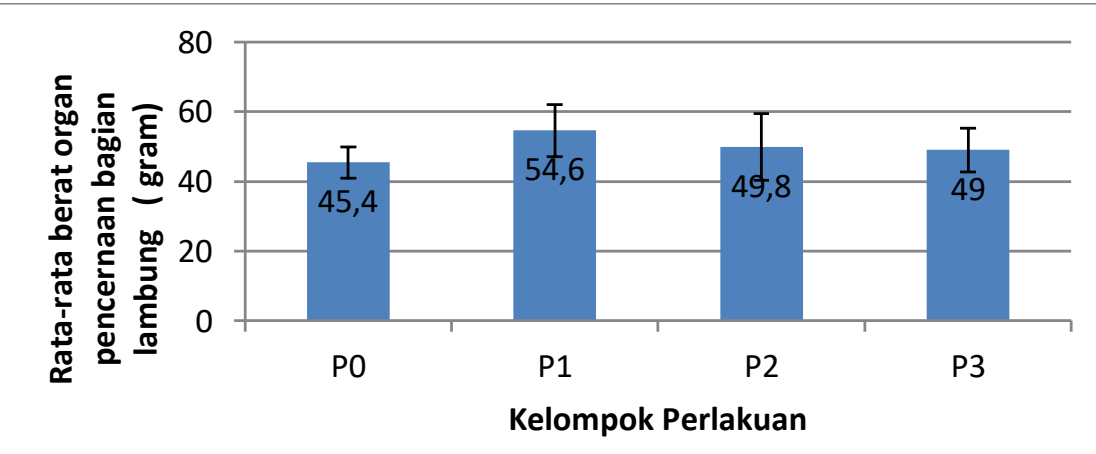

Gambar 1. Diagram berat lambung rata-rata setiap kelompok perlakuan 
2. Berat organ usus halus

Hasil berat organ pencernaan bagaian usus halus adalah sebagai berikut:

Berdasarkan hasil analisis uji statistik menunjukkan tidak terdapat perbedaan yang nyata antara kelompok perlakuan dan kontrol ( $\mathrm{P}>0.05)$, hasil statistik dapat dilihat pada tabel. Hal ini dapat disebabkan karena kandungan nutrisi dalam pakan yang digunakan antara kelompok perlakuan dan kontrol tidak terdapat perbedaan yang signifikan. Usus halus merupakan tempat penyerapan nutrisi pakan, proses penyerapan nutrisi dipengaruhi oleh beberapa faktor yaitu bentuk pakan, kecepatan pakan melewati organ pencernaan, besar kecilnya partikel pakan, luas area penyerapan, serta fisiologis usus sendiri (Sukaryana, dkk., 2011).

Kapasitas dari usus mempengaruhi kemampuan usus dalam mencerna pakan, semakin luas area penyerapan maka semakin besar kemampuannya dalam menyerap nutrisi pakan (Hidayat, dkk., 2016). Faktor-faktor yang merangsang perkembangan usus halus yaitu nutrisi yang dicerna seperti protein, lemak, dan pati. Protein berperan dalam pembentukan jaringan.

Sebagain besar nutrisi yang diserap usus akan digunakan oleh usus sendiri untuk menjaga fungsi dan proses regenerasi dari sel usus sendiri. Protein dan lemak dalam pakan yang dicerna oleh usus halus memiliki fungsi sebagai pembentuk jaringan dan merangsang poliferasi sel, maka semakin tinggi protein dan lemak yang dapat dicerna oleh usus maka semakin cepat kemampuan usus dalam meregenerasi sel-selnya sehingga menyebabkan ukuran dari vili semakin panjang dan juga lumen usus semakin besar sehingga menyebabkan pencernaan semakin tinggi (Hidayat, dkk., 2016; Hartono, dkk., 2016).

Tabel 2.Berat usus halus rata-rata setiap kelompok perlakuan

\begin{tabular}{cc}
\hline Perlakuan & Rata-rata $(\mathrm{g}) \pm \mathrm{SD}$ \\
\hline P0 & $76,60 \pm 7,66$ \\
P1 & $92,20 \pm 13,53$ \\
P2 & $80,20 \pm 14,46$ \\
P3 & $77,80 \pm 15,57$ \\
\hline
\end{tabular}

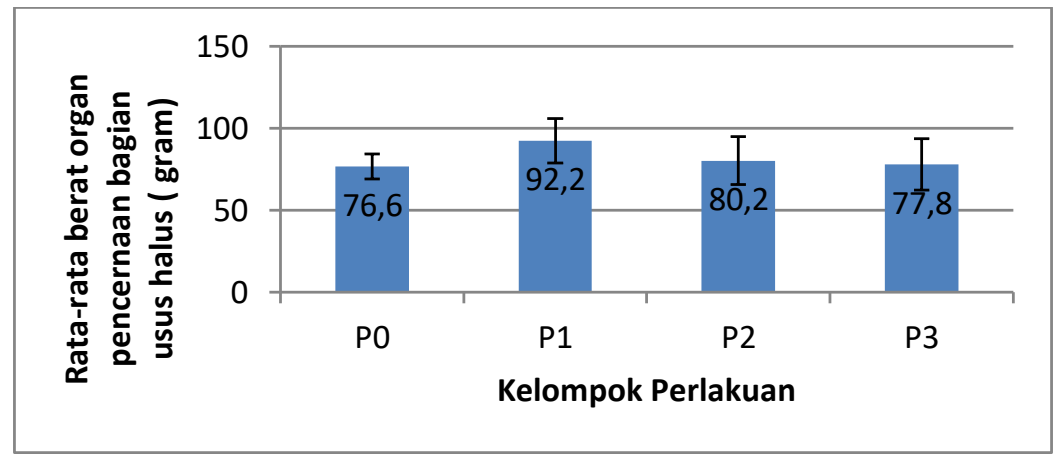

Gambar 2. Diagram berat usus halus rata-rata setiap kelompok perlakuan

3. Berat organ usus besar

Hasil berat organ pencernaan bagaian usus besar adalah sebagai berikut:

Berdasarkan hasil analisis uji statistik menunjukkan bahwa tidak terdapat perbedaan yang nyata antara kelompok perlakuan dan kontrol ( $\mathrm{P}>0.05)$, hasil statistik dapat dilihat pada tabel 3 . Peningkatan ini disebabkan karena kandungan nutrisi dalam pakan yang digunakan antara kelompok perlakuan dan kontrol tidak terdapat perbedaan yang signifikan. Faktor yang mempengaruhi ukuran dari pada caecum yaitu jumlah pakan 
yang dikonsumsi, usia, dan serat kasar dalam pakan. Semakin besar kemampuan dari caecum dalam menampung pakan memiliki pengaruh yang sangat besar terhadap proses fermentasi sehingga jumlah
VFA yang dihasilkan akan semakin banyak. Semakin banyaknya VFA yang dihasilkan maka akan mempengaruhi poliferasi sel lebih tinggi dan akan menyebabkan organ lebih berat (Sutrisna, 2017).

Tabel 3.Berat usus besar rata-rata setiap kelompok perlakuan

\begin{tabular}{cc}
\hline Perlakuan & Rata-rata $(\mathrm{g}) \pm \mathrm{SD}$ \\
\hline P0 & $182,00 \pm 18,30$ \\
P1 & $219,80 \pm 31,13$ \\
P2 & $201,40 \pm 36,71$ \\
P3 & $196,60 \pm 25,44$ \\
\hline
\end{tabular}

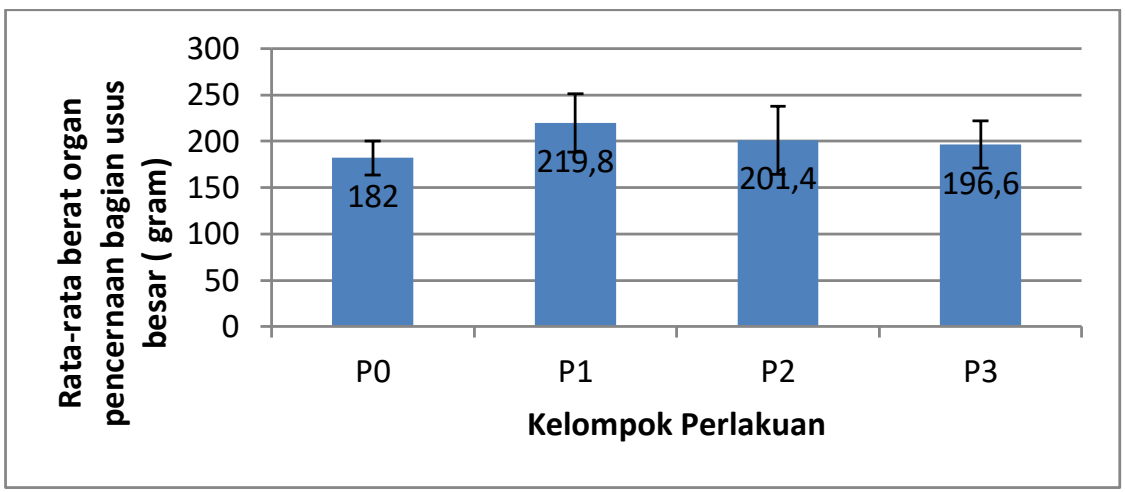

Gambar 3. Diagram berat usus besar rata-rata setiap kelompok perlakuan

4. Persentase Lemak Abdominal

Hasil persentase lemak abdominal pada penelitian ini adalah sebagai berikut :

Berdasarkan hasil analisis ragam menunjukkan bahwa tidak terdapat perbedaan yang nyata antar kelompok perlakuan dan kontrol ( $p>0.05)$ terhadap persentase lemak abdominal. Hal ini diduga disebabkan karena kandungan nutrisi dalam ransum yang dikonsumsi kelinci tidak jauh berbeda. Timbunan lemak abdomen pada tubuh dipengaruhi oleh beberapa faktor antara lain genetik, nutrisi, jenis kelamin, umur dan faktor lingkungan (Tumuva and Teimouri 2010). Jenis kelamin dan umur diketahui memiliki pengaruh yang besar terhadap deposisi lemak dalam tubuh (Novele et al., 2008). Faktor lingkungan ikut mempengaruhi deposisi lemak abdomen dalam tubuh. Faktor lingkungan antara lain suhu lingkungan, sistem perkandangan, serta sistem pencahayaan. Setiawan dan Sujana (2009), menyatakan bahwa pembentukan lemak abdominal terjadi karena adanya kelebihan energi yang dikonsumsi.

Tabel 4. Nilai persentase (\%) lemak abdominal dan simpangan baku kelinci pedaging yang diberi pakan sesuai dengan perlakuan masing-masing.

\begin{tabular}{cc}
\hline Perlakuan & Niai rata-rata \pm SD $(\%)$ \\
\hline P0 & $0,03 \pm 0,578$ \\
P1 & $0,08 \pm 0,435$ \\
P2 & $0,06 \pm 0,582$ \\
P3 & $0,04 \pm 0,729$ \\
\hline
\end{tabular}




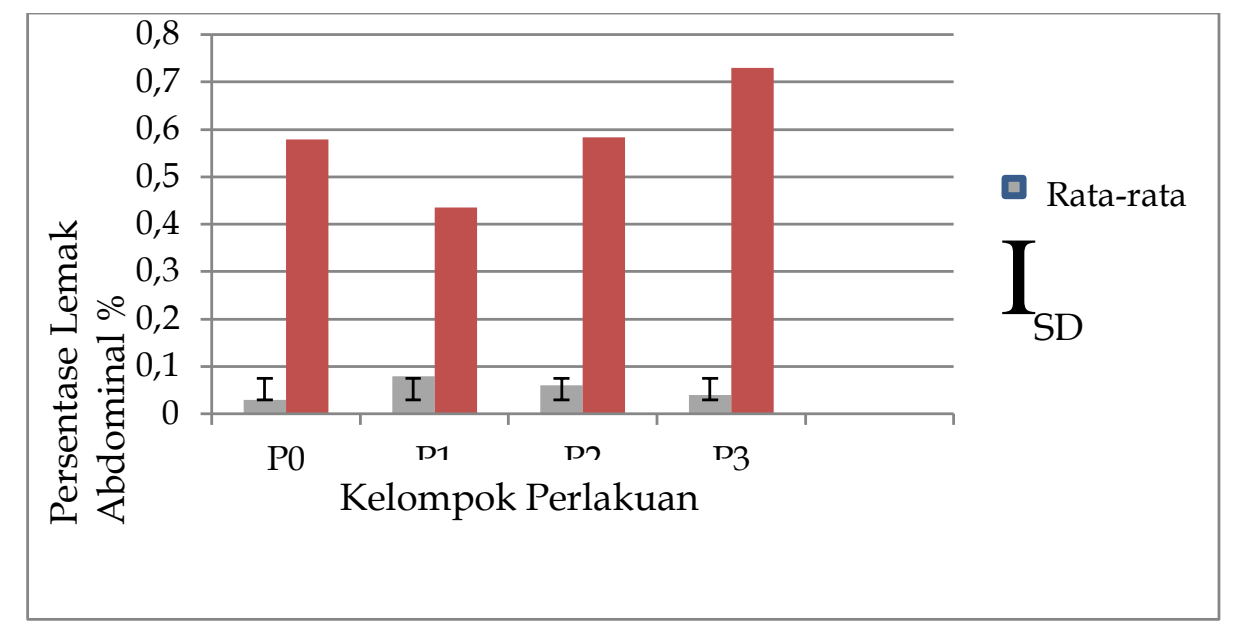

Gambar 4. Diagram Batang Persentase Lemak Abdominal Kelinci Pedaging

Energi yang digunakan tubuh umumnya berasal dari karbohidrat dalam tubuh mampu memproduksi lemak tubuh yang tersimpan di sekeliling organ dalam dan di bawah kulit. Didukung dengan pernyataan Raharjo dan Brahmantiyo (2009), bahwa perlemakan subkutan dan abdomen kelinci akan tinggi dengan bobot potong yang tinggi.

\section{KESIMPULAN}

Penggunaan tepung teritip (Cirripedia Sp.) sebagai feed substitusi tepung ikan dalam pakan Complete feed kelinci tidak berpengaruh secara nyata terhadap berat organ pencernaan kelinci bagian lambung, usus halus, usus besar dan lemak abdominal kelinci.

\section{DAFTAR PUSTAKA}

Arimbi, A., Azmijah, R., Darsono, H., Plumeriastuti, T., Widiyatno, D., \& Legowo. (2015). Buku Ajar Patologi Umum Veteriner (2nd ed.). Surabaya: Airlangga Unversity Press.

Citrawidi. T, Murningsih, W., \& Ismadi, V. (2012). Pengaruh pemeraman ransum dengan sari daun pepaya terhadap kolesterol darah dan lemak total ayam broiler. Animal Agriculture Journal , 1(1), 529-540.
Ermaitis. (1984). Beberapa Catatan Tentang Marga Balanus (Cirripedia). In Oceana (9th ed., pp. 96 - 101). Jakarta: LON-LIPI.

Giritya, E. (2013). Pengaruh Pakan Komplit Terhadap Nilai Kecernaan Protein Pada Sapi Perah. Surabaya: Fakultas Kedokteran Hewan. Universitas Airlangga.

Hartono, E. F., Iriyanti, N., \& Suhermiyati, S. (2016). Efek penggunaan sinbiotik terhadap kondisi miklofora dan histologi usus ayam sentul jantan. Jurnal Agripet, 16(2), 97-105. https://doi.org/10.17969/agripet.v16i2 .5179

Hidayat, S. C. M., Harimurti, S., \& Yusiati, L. M. (2016). Pengaruh suplementasi probiotik bakteri asam laktat terhadap histomorfologi usus dan performan puyuh jantan. Buletin Peternakan, 40(2), 101-106. https://doi.org/10.21 059/buletinpeternak.v40i2.9072

Low, A. G. (1980). Nutrient absorption in pigs. Journal of the Science of Food and Agriculture, 31(11), 1087-1130. https://doi.org/10.1002/jsfa.2740311102

Mirza, N., Dewiyanti, I., \& Octavina, C. (2017). Kepadatan teritip (Balanus Sp.) di kawasan rehabilitasi mangrove 
pemukiman Rigaih Kecamatan Setia Bakti Kabupaten Aceh Jaya, Provinsi Aceh. Jurnal Ilmiah Mahasiswa Kelautan Perikanan Unsyiah, 2(4), 534-540.

Novele, D. J., Ng`Ambi, J. W., Norris, D., \& Mbajiorgu, C. A. (2008). Effect of sex, level and period of feed restriction during the starter stage on productivity and carcass characteristics of ross 308 broiler chickens in South Africa. International Journal of Poultry Science, 7(6), 530-537. https://doi.org /10.3923/ijps.2008.530.537

Raharjo, Y., \& Brahmantiyo, B. R. A. (2014). Plasma nutfah kelinci sebagai sumber pangan hewani dan produk lain bermutu tinggi. Indonesian Journal of Animal and Veterinary Sciences, 19(3).

Rahmaningtyas, I., Yulianto, R., Prastika, D. W., Arifin, K., Oktaviana, V., Setiabudi, R. S., \& Purnama, M. T. E. (2012). Efektivitas tepung teritip (cirripedia sp) terhadap pertambahan berat badan dan feed convertion ratio (fcr) ayam pedaging. Surabaya. Jurnal Agro Veteriner, 5(2), 170-174.

Setiawan, I., \& Sujana, E. (2019). Bobot akhir, persentase karkas dan lemak abdominal ayam broiler yang dipanen pada umur yang berbeda. Journal of Chemical Information and Modeling, 563-567.

Siregar, G. A. W., Nuraini, H., \& Rahmantiyo, B. (2017). Pertumbuhan dan produksi karkas kelinci rex pada umur potong yang berbeda. Jurnal Ilmu Produksi Dan Teknologi Hasil Peternakan, 2(1), 196-200.
Sutrisna, R. (2017). Pengaruh beberapa tingkat serat kasar dalam ransum terhadap pekembangan organ dalam itik jantan. Jurnal Penelitian Pertanian Terapan, 12(1), 1-5. https: //doi.org/10.25181/JPPT.V12I1.191

Tambunan, M. H. (2015). Pengaruh pemberian tepung daun indigofera $\mathrm{sp}$ terhadap konsumsi, pertambahan bobot badan dan efisiensi ransum kelinci peranakan new zealand white. Students E-Journal, 4(1), 1-11.

Tumuva, E., \& Teimouri, A. (2010). Fat deposition in the broiler chicken: a review. Journal Scientia Agriculturae Bohemica, 41, 121-128. https://doi. org/10.25181/jppt.v12i1.191

Usman, \& Tiro, B. M. (2015). Perbedaan pola pemeliharaan terhadap produktivitas ternak kelinci di Kabupaten Lanny Jaya, Papua. Agroscientiae, 17(1), 95-102.

Utama, F. H., Kamila, K., \& Latipudin, D. (2014). Sekret Mucus Sel Goblet Ileum dan Ukuran Usus Halus Puyuh (Coturnix coturnix japonica) yang diberi Bawang Putih (Allium sativum). Bandung: Fakultas Peternakan Universitas Padjadjaran.

Wresdiyati, T., Setiorini, Y., Laila, S. R., Arief, I. I., \& Astawan, M. (2013). Probiotik lokal meningkatkan kandungan iga usus halus tikus yang diinfeksi enteropathogenic E.Coli (Epec): studi imunohistokimia. Jurnal Kedokteran Hewan - Indonesian Journal of Veterinary Sciences, 7(2), 78-85. https://doi.org/10.21157/j.ked .hewan.v7i2.921 